\title{
Analyst
}

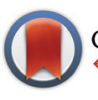

CrossMark

Cite this: Analyst, 2015, 140, 6283

\section{Detection and quantification of new psychoactive substances (NPSs) within the evolved "legal high" product, NRG-2, using high performance liquid chromatography-amperometric detection (HPLC-AD)}

\author{
Khaled Y. Zuway, ${ }^{a}$ Jamie P. Smith, ${ }^{a}$ Christopher W. Foster, ${ }^{a}$ Nikil Kapur, ${ }^{b}$ \\ Craig E. Banks*a and Oliver B. Sutcliffe ${ }^{\star^{a}}$
}

\begin{abstract}
The global increase in the production and abuse of cathinone-derived New Psychoactive Substances (NPSs) has developed the requirement for rapid, selective and sensitive protocols for their separation and detection. Electrochemical sensing of these compounds has been demonstrated to be an effective method for the in-field detection of these substances, either in their pure form or in the presence of common adulterants, however, the technique is limited in its ability to discriminate between structurally related cathinone-derivatives (for example: $( \pm)$-4'-methylmethcathinone (4-MMC, 2a) and ( \pm )-4'-methyl$\mathrm{N}$-ethylmethcathinone (4-MEC, $\mathbf{2 b}$ ) when they are both present in a mixture. In this paper we demonstrate, for the first time, the combination of HPLC-UV with amperometric detection (HPLC-AD) for the qualitative and quantitative analysis of 4-MMC and 4-MEC using either a commercially available impinging jet (LC-FC-A) or custom-made iCell channel (LC-FC-B) flow-cell system incorporating embedded graphite screen-printed macroelectrodes. The protocol offers a cost-effective, reproducible and reliable sensor platform for the simultaneous HPLC-UV and amperometric detection of the target analytes. The two systems have similar limits of detection, in terms of amperometric detection [LC-FC-A: $14.66 \mu \mathrm{g} \mathrm{m} \mathrm{L}^{-1}$ (2a) and $9.35 \mu \mathrm{g} \mathrm{mL}{ }^{-1}$ (2b); LC-FC-B: $57.92 \mu \mathrm{g} \mathrm{mL} \mathrm{L}^{-1}$ (2a) and $26.91 \mu \mathrm{g} \mathrm{mL} \mathrm{L}^{-1}$ (2b)], to the previously reported oxidative electrochemical protocol [39.8 $\mathrm{gg} \mathrm{mL}^{-1}(\mathbf{2 a})$ and $84.2 \mu \mathrm{g} \mathrm{mL^{-1 }}$ (2b)], for two synthetic cathinones, prevalent on the recreational drugs market. Though not as sensitive as standard HPLC-UV detection, both flow cells show a good agreement, between the quantitative electroanalytical data, thereby making them suitable for the detection and quantification of 4-MMC and 4-MEC, either in their pure form or within complex mixtures. Additionally, the simultaneous HPLC-UV and amperometric detection protocol detailed herein shows a marked improvement and advantage over previously reported electroanalytical methods, which were either unable to selectively discriminate between structurally related synthetic cathinones (e.g. 4-MMC and 4-MEC) or utilised harmful and restrictive materials in their design.
\end{abstract}

Received 2nd June 2015, Accepted 27th July 2015 DOI: 10.1039/c5an01106j www.rsc.org/analyst

\section{Introduction}

Over the past few years there has been a striking increase in the global sale of New Psychoactive Substances (NPS) colloquially termed "legal highs". ${ }^{1}$ These substances can be purchased through the Internet, as cheap and legal replacements for controlled stimulants such as methamphetamine and MDMA. Since 2010, first generation cathinone-derived NPS (e.g.

${ }^{a}$ Faculty of Science and Engineering, School of Science and the Environment, Division of Chemistry and Environmental Science, Manchester Metropolitan University, Chester Street, Manchester M1 5GD, UK. E-mail: o.sutcliffe@mmu.ac.uk, c.banks@mmu.ac.uk; Fax: +44-(0)-161-247-6831; Tel: +44-(0)-161-247-1531, +44-(0)-161-247-1196

${ }^{b}$ School of Mechanical Engineering, University of Leeds, Leeds LS2 9JT, UK mephedrone (4-MMC, 2a) and 4-MEC (2b); Scheme 1) have become controlled in many countries worldwide. ${ }^{2,3}$ Since the legislative change, a number of evolved New Psychoactive Substance products, such as NRG-1 (naphyrone) and NRG-2 (Scheme 1), which are advertised to contain legal cathinone substitutes, have become widely available. ${ }^{3,4}$ However, many of these second generation products have been found to contain structurally related cathinone derivatives that are themselves, like naphyrone, controlled substances. ${ }^{3,4}$ Although many groups have reported analytical methods and structural data for many cathinone-derivatives, ${ }^{3,5}$ including those found in samples of NRG-2, the prevalence of novel cathinones (especially $4-\mathrm{MMC}^{2,6}$ and $4-\mathrm{MEC}^{3,7}$ ) both as pure materials or within blended "legal high" products, continue to pose legal and analytical challenges in the rapid detection of these sub- 
a, c<smiles>CCC(=O)c1ccc(C)cc1</smiles>

(1)

.

stances by law enforcement, medical and customs officials especially as many of the current methods of field tests are unable to reliably discern individual components with a mixture of compounds. ${ }^{8}$

Electrochemistry is an advantageous analytical tool that is adaptable to an in-the-field device, in light of its portability, and can exhibit sensitivity and selectivity toward many target analytes. ${ }^{5,8-14}$ Our previous work on the development of robust electrochemical methods for the sensing of the synthetic cathinones, mephedrone (2a) and 4-MEC (2b), either in their pure form $^{5}\left(\mathrm{LOD}=39.8-84.2 \mu \mathrm{g} \mathrm{mL} \mathrm{m}^{-1}\right)$, using electroanalytical oxidation, or in the presence of common adulterants ${ }^{15}$ (i.e. products containing synthetic cathinones in combination with caffeine or benzocaine) (LOD $=11.6-11.8 \mu \mathrm{g} \mathrm{mL}^{-1}$ ), using direct electrochemical reduction, has the potential to be rapid, simple and cost-effective on-the-spot analytical screening tools with graphite screen-printed macroelectrodes (GSPEs). Krishnaiah et al. have also reported the electrochemical reduction of mephedrone $\left(2 \mathrm{a}, \mathrm{LOD}=2.2 \times 10^{-3} \mu \mathrm{g} \mathrm{mL}^{-1}\right)$ using a dropping mercury electrode (DME). ${ }^{16}$ Though sensitive, the use of DME for in-field sensors is restrictive, as mercury is widely considered harmful and its use is banned in numerous countries. ${ }^{17-20}$

Though our initial work has indicated the application of GSPEs to the electrochemical detection of synthetic cathinones ${ }^{5}$ and demonstrated an excellent agreement between our electroanalytical protocol and that of high performance-liquid chromatography (HPLC) for street samples ${ }^{15}$ the ability to simultaneously detect and quantify structurally related cathinones (for example: 4-MMC and 4-MEC within a single sample) eluded us due to co-incident voltammetric waves for the target analytes. ${ }^{5}$ The application of electrochemical detection (ED) in HPLC has been used for a range of areas including toxicology, therapeutic drug monitoring, drug metabolism and pharmacokinetics, ${ }^{21-23}$ however, the application of the technique towards the analysis of synthetic cathinones remains unexplored. Consequently in this paper, for the first time, the direct combination of HPLC with electrochemical detection for the qualitative and quantitative analysis of synthetic cathinones (4-MMC and 4-MEC) is reported using both a commercially available impinging jet flow cell (Dropsens, FC-A, Fig. 1a and b) and a custom-made iCell channel flow-cell (University of Leeds, FC-B, Fig. 1c and d $)^{24}$ incorporating embedded GSPE macroelectrodes. GSPEs offer a cost-effective, reproducible and reliable sensor platform for the amperometric detection (AD) of the target analytes and the validated technique, high performance liquid chromatography-amperometric detection (HPLC-AD), has been shown to be suitable for the routine detection and quantification of the two synthetic cathinones either in their pure form, in the presence of common adulterants (e.g. caffeine) or simultaneously within blended street samples of the evolved "legal high" product, NRG-2.

\section{Experimental}

All chemicals were of analytical grade, obtained from commercial sources (Sigma-Aldrich, Gillingham, UK) and used without any further purification. All solutions were prepared with deionised water of resistively $\geq 18.2 \Omega \mathrm{cm}$. All solutions (unless stated otherwise) were vigorously degassed with nitrogen to remove oxygen prior to analysis. Five street samples of NRG-2 were obtained from independent Internet vendors (January 2013), as off-white crystalline powders, in clear zip-lock bags. LC-MS analysis was performed independently to quantify the chemical composition of the NRG-2 samples. ${ }^{3,15}$

The two flow cells used in this study were obtained from Metrohm UK, Runcorn, UK (impinging jet flow cell; product code: DRP-FLWCL-TEF-71306; $3.3 \times 6.0 \times 3.3 \mathrm{~cm}$, flow chamber volume $=8 \mu \mathrm{L}$; denoted as FC-A, Fig. $1 \mathrm{a}$ and $\mathrm{b}$ ) or the University of Leeds, UK (iCell channel flow cell; $4.5 \times 4.5 \times 4.0 \mathrm{~cm}$, flow-chamber volume $=120 \mu \mathrm{L}$; denoted as FC-B, Fig. $1 \mathrm{c}$ and d). The iCell (FC-B) was fabricated as previously reported. ${ }^{24}$ Graphite screen-printed macroelectrodes (GSPEs) with a working electrode ( $3 \mathrm{~mm}$ diameter) were fabricated in-house 

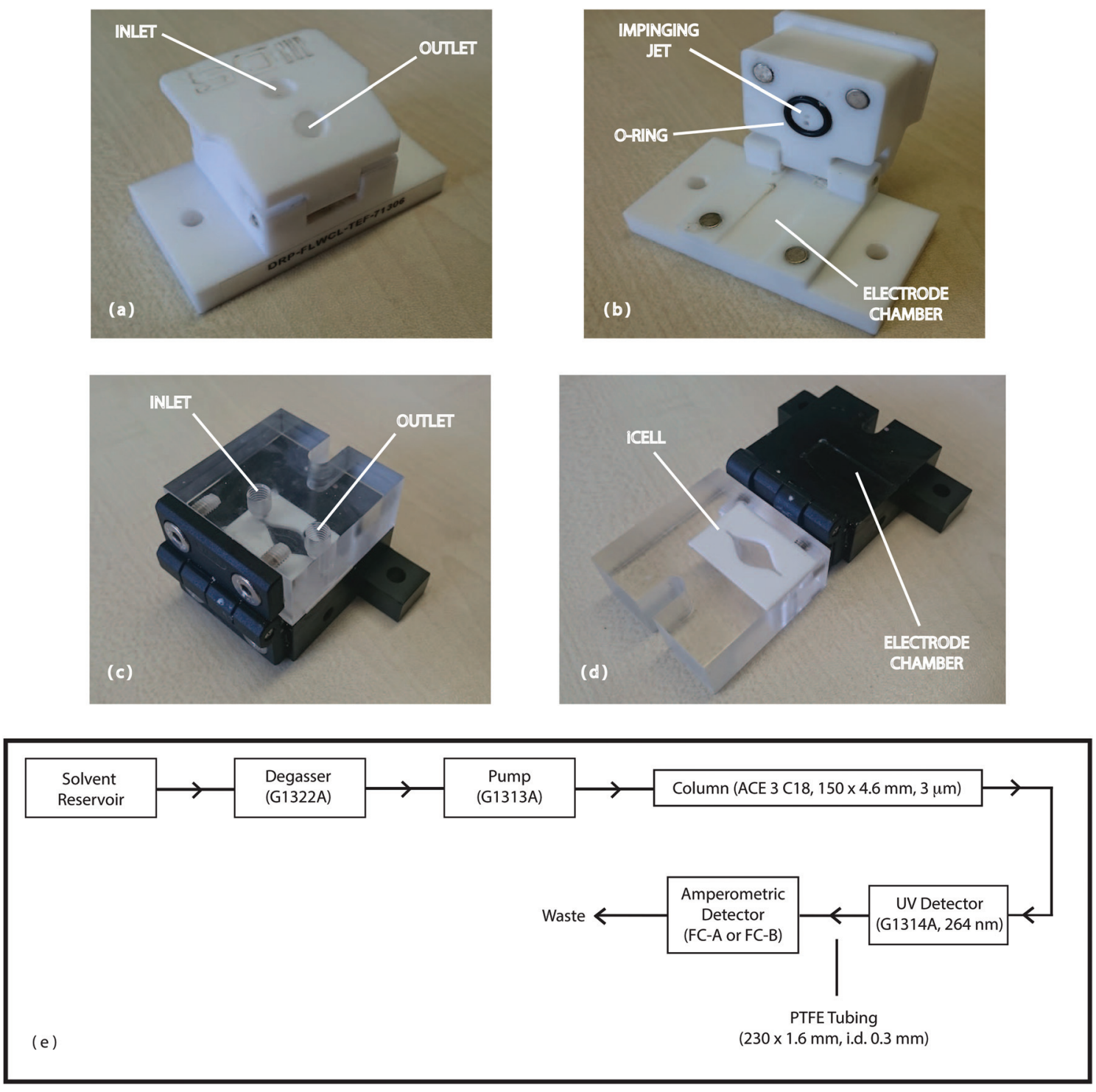

Fig. 1 (a) Impinging jet flow cell (FC-A; DRP-FLWCL-TEF-71306; $3.3 \times 6.0 \times 3.3 \mathrm{~cm}$, flow chamber volume $=8 \mu \mathrm{L}$, closed); (b) impinging jet flow cell (FC-A; DRP-FLWCL-TEF-71306; $3.3 \times 6.0 \times 3.3 \mathrm{~cm}$, flow chamber volume $=8 \mu \mathrm{L}$, open); (c) iCell channel flow cell (FC-B; $4.5 \times 4.5 \times 4.0 \mathrm{~cm}$, flow-chamber volume $=120 \mu \mathrm{L}$, closed); (d) iCell channel flow cell (FC-B; $4.5 \times 4.5 \times 4.0 \mathrm{~cm}$, flow-chamber volume $=120 \mu \mathrm{L}$, open); (e) flow diagram of the High Performance Liquid Chromatography-Amperometric Detection (HPLC-AD) systems (LC-FC-A and LC-FC-B),

with appropriate stencil designs using a DEK 248 screen-printing machine (DEK, Weymouth, UK). ${ }^{13}$ For the fabrication of the screen-printed sensors, firstly, a carbon-graphite ink formulation (Gwent Electronic Materials Ltd, UK; product code: C2000802P2) was screen-printed onto a polyester (Autostat, $250 \mu \mathrm{m}$ thickness) flexible film (denoted throughout as GSPEs). This layer was cured in a fan oven $\left(60^{\circ} \mathrm{C} / 30 \mathrm{~min}\right)$ and an $\mathrm{Ag} / \mathrm{AgCl}$ reference electrode incorporated by screen-printing $\mathrm{Ag} / \mathrm{AgCl}$ paste (Gwent Electronic Materials Ltd, UK; product code: C2040308D2) onto the polyester substrate. Finally, a dielectric paste (Gwent Electronic Materials Ltd, UK; product code: D2070423D5) was then printed onto the polyester substrate to cover the connections. After curing $\left(60^{\circ} \mathrm{C} / 30 \mathrm{~min}\right)$ the screen-printed electrodes are ready to be used. Note that a new
GSPE was utilized for each experiment performed, including during the "street sample" analysis study.

\section{Synthesis}

The synthetic cathinone hydrochloride (or hydrobromide) salts, were prepared at the University of Strathclyde prior to the legislative change on $16^{\text {th }}$ April 2010 using the previously reported methods from (1). ${ }^{2,3}$ To ensure the authenticity of the materials utilised in this study the synthesised samples were fully structurally characterised (vide infra) and the purity of both samples was confirmed by elemental analysis ( $>99.5 \%$ in all cases). ${ }^{1} \mathrm{H}$ and ${ }^{13} \mathrm{C}$ NMR spectra were acquired on both JEOL AS-400 (JEOL, Tokyo, Japan) and Bruker Avance 400 (Bruker, Karlsruhe, Germany) NMR spectrometers operating at 
a proton resonance frequency of $400 \mathrm{MHz}$. Infrared spectra were obtained in the range $4000-400 \mathrm{~cm}^{-1}$ using a ThermoScientific Nicolet iS10ATR-FTIR instrument (ThermoScientific, Rochester, USA). Mass spectra were recorded on a ThermoScientific LTQ ORBITRAP mass spectrometer (ThermoScientific, Rochester, USA) using electrospray ionisation. Ultraviolet spectra were obtained using a Unicam 300 UV spectrophotometer (ThermoScientific, Rochester, USA). Thin-Layer Chromatography (TLC) was carried out on aluminium-backed $\mathrm{SiO}_{2}$ plates (Merck, Darmstadt, Germany) and spots were visualised using ultra-violet light $(254 \mathrm{~nm})$. Microanalysis was carried out using a PerkinElmer 2400 Series II elemental analyser (PerkinElmer, San Jose, USA). Melting points were determined using differential scanning calorimetry (DSC; Netzsch STA449 C, Netzsch-Gerätebau, Wolverhampton, UK). Optical rotation values $[\alpha]_{\mathrm{D}}^{22}\left(10^{-1} \mathrm{deg} \mathrm{cm}^{2} \mathrm{~g}^{-1}\right)$ were performed on a Bellingham \& Stanley ADP-220 polarimeter (Bellingham \& Stanley, Tunbridge Wells, UK).

$( \pm)-4$ '-Methylmethcathinone hydrochloride $[( \pm)$-mephedrone hydrochloride] (4-MMC, 2a). Yield $=51.2 \%$ (from 1); Mpt. (acetone) $251.18{ }^{\circ} \mathrm{C} ; R_{\mathrm{f}}\left[\mathrm{SiO}_{2}\right.$, EtOAc: $n$-hexane $\left.(1: 3)\right]=0.11$; $[\alpha]_{\mathrm{D}}^{22}=0(c=0.5 \mathrm{~g}$ per $100 \mathrm{~mL}$ in $\mathrm{MeOH})$; Found: $\mathrm{C}, 61.81 ; \mathrm{H}$, 7.52; N, 6.57. $\mathrm{C}_{11} \mathrm{H}_{16} \mathrm{ClNO}$ requires $\mathrm{C}, 61.82 ; \mathrm{H}, 7.55$ and $\mathrm{N}$, $6.55 \%$; UV (EtOH): $\lambda_{\max }=259.5 \mathrm{~nm}\left(A=0.735, c=9.95 \times 10^{-4} \mathrm{~g}\right.$ per $100 \mathrm{~mL})$; IR (ATR-FTIR): $2717.5\left(\mathrm{NH}_{2}^{+}\right), 1689.5(\mathrm{C}=\mathrm{O})$, $1606.3 \mathrm{~cm}^{-1}(\mathrm{C}=\mathrm{C}) ;{ }^{1} \mathrm{H}$ NMR (400 MHz, $60{ }^{\circ} \mathrm{C}, d_{6}$-DMSO) $\delta{ }^{1} \mathrm{H}$ $(\mathrm{ppm})=9.35\left(2 \mathrm{H}\right.$, br s, $\left.\mathrm{CH}\left(\mathrm{NH}_{2}{ }^{+} \mathrm{CH}_{3}\right) \mathrm{CH}_{3}\right) ; 7.96(2 \mathrm{H}, \mathrm{d}, J=8.3$ $\left.\mathrm{Hz}, \mathrm{AA}^{\prime} \mathrm{BB}^{\prime}\right), 7.41\left(2 \mathrm{H}, \mathrm{d}, J=8.3 \mathrm{~Hz}, \mathrm{AA}^{\prime} \mathrm{BB}^{\prime}\right), 5.08(1 \mathrm{H}, \mathrm{q}, J=7.2$ $\left.\mathrm{Hz}, \mathrm{CH}\left(\mathrm{NH}_{2}{ }^{+} \mathrm{CH}_{3}\right) \mathrm{CH}_{3}\right), 2.59\left(3 \mathrm{H}, \mathrm{s}, \mathrm{CH}\left(\mathrm{NH}_{2}{ }^{+} \mathrm{CH}_{3}\right) \mathrm{CH}_{3}\right), 2.41$ $\left(3 \mathrm{H}, \mathrm{s}, \mathrm{ArCH} \mathrm{H}_{3}\right)$ and $1.46\left(3 \mathrm{H}, \mathrm{d}, J=7.2 \mathrm{~Hz}, \mathrm{CH}\left(\mathrm{NH}_{2}{ }^{+} \mathrm{CH}_{3}\right) \mathrm{CH}_{3}\right)$; ${ }^{13} \mathrm{C}$ NMR (400 MHz, $60{ }^{\circ} \mathrm{C}, d_{6}$-DMSO) $\delta{ }^{13} \mathrm{C}(\mathrm{ppm})=195.8$ $(\mathrm{C}=\mathrm{O}, \mathrm{C} 1), 145.5$ (ArC, C4'), 130.4 (ArC, C1'), 129.7 (2 × ArCH, $\left.\mathrm{C}^{\prime} / \mathrm{C}^{\prime}\right), 128.9\left(2 \times \mathrm{ArCH}, \mathrm{C}^{\prime} / \mathrm{C}^{\prime}\right), 58.1\left(\mathrm{CHCH}_{3}, \mathrm{C} 2\right), 30.6$ $\left(\mathrm{NH}_{2}{ }^{+} \mathrm{CH}_{3}\right), 21.2\left(\mathrm{ArCH}_{3}, \mathrm{C}^{\prime}\right)$ and $15.5\left(\mathrm{CHCH}_{3}, \mathrm{C} 3\right)$; LRMS $\left(\mathrm{ESI}^{+}, 70 \mathrm{eV}\right): m / z=178\left(6,[\mathrm{M}+\mathrm{H}]^{+}\right), 160$ (47), 145 (100), 130 (7), 119 (16) and 91 (5\%); HRMS (ESI $\left.{ }^{+}, 70 \mathrm{eV}\right)$ calculated for [M $+\mathrm{H}] \mathrm{C}_{11} \mathrm{H}_{16} \mathrm{NO}$ : 178.1226, found: 178.1226 .

$( \pm)-4^{\prime}$-Methyl- $N$-ethylcathinone hydrobromide (4-MEC, 2b). Yield $=41.5 \%$ (from 1); Mpt. (acetone) $206.08{ }^{\circ} \mathrm{C} ; R_{\mathrm{f}}\left[\mathrm{SiO}_{2}\right.$, EtOAc : $n$-hexane $(1: 3)]=0.10 ;[\alpha]_{\mathrm{D}}^{22}=0(c=0.5 \mathrm{~g}$ per $100 \mathrm{~mL}$, $\mathrm{MeOH}$ ); found: $\mathrm{C}, 52.90 ; \mathrm{H}, 6.65 ; \mathrm{N}, 4.95 . \mathrm{C}_{12} \mathrm{H}_{18} \mathrm{BrNO}$ requires C, 52.95; H, 6.67 and N, 5.15\%; UV (EtOH): $\lambda_{\max }=260.0 \mathrm{~nm}(A$ $=0.693, c=1.02 \times 10^{-3} \mathrm{~g}$ per $100 \mathrm{~mL}$ ); IR (ATR-FTIR): 2735.4 $\left(\mathrm{NH}_{2}{ }^{+}\right), 1687.3(\mathrm{C}=\mathrm{O}), 1605.4 \mathrm{~cm}^{-1}(\mathrm{C}=\mathrm{C}) ;{ }^{1} \mathrm{H}$ NMR $(400 \mathrm{MHz}$, $60{ }^{\circ} \mathrm{C}, \quad d_{6}$-DMSO $) \quad \delta{ }^{1} \mathrm{H}(\mathrm{ppm})=8.92(2 \mathrm{H}$, br $\mathrm{s}, \mathrm{CH}$ $\left.\left(\mathrm{NH}_{2}{ }^{+} \mathrm{CH}_{2} \mathrm{CH}_{3}\right) \mathrm{CH}_{3}\right) ; 7.98\left(2 \mathrm{H}, \mathrm{d}, J=8.4 \mathrm{~Hz}, \mathrm{AA}^{\prime} \mathrm{BB}^{\prime}\right), 7.41(2 \mathrm{H}$, $\left.\mathrm{d}, J=8.4 \mathrm{~Hz}, \mathrm{AA}^{\prime} \mathrm{BB}^{\prime}\right), 5.21\left(1 \mathrm{H}, \mathrm{q}, J=6.8 \mathrm{~Hz}, \mathrm{CH}\left(\mathrm{NH}_{2}{ }^{+} \mathrm{CH}_{2} \mathrm{CH}_{3}\right)\right.$ $\mathrm{CH}_{3}$ ), 3.04 (2H, dq, $J=12.4,7.2 \mathrm{~Hz}, \mathrm{CH}\left(\mathrm{NH}_{2}{ }^{+} \mathrm{CH}_{2} \mathrm{CH}_{3}\right) \mathrm{CH}_{3}$ ), $2.42\left(3 \mathrm{H}, \mathrm{s}, \mathrm{ArCH} \mathrm{H}_{3}\right), 1.53\left(3 \mathrm{H}, \mathrm{d}, J=7.2 \mathrm{~Hz}, \mathrm{CH}\left(\mathrm{NH}_{2}{ }^{+} \mathrm{CH}_{2} \mathrm{CH}_{3}\right)\right.$ $\left.\mathrm{CH}_{3}\right)$ and $1.28 \mathrm{ppm}\left(3 \mathrm{H}, \mathrm{t}, J=7.2 \mathrm{~Hz}, \mathrm{CH}\left(\mathrm{NH}_{2}{ }^{+} \mathrm{CH}_{2} \mathrm{CH}_{3}\right) \mathrm{CH}_{3}\right)$; ${ }^{13} \mathrm{C}$ NMR (100 MHz, $60{ }^{\circ} \mathrm{C}, d_{6}$-DMSO) $\delta{ }^{13} \mathrm{C}(\mathrm{ppm})=195.5$ $(\mathrm{C}=\mathrm{O}, \mathrm{C} 1), 145.2\left(\mathrm{ArC}, \mathrm{C} 4^{\prime}\right), 130.2\left(\mathrm{ArC}, \mathrm{C} 1^{\prime}\right), 129.4$ (2× $\mathrm{ArC}$, $\left.\mathrm{C}^{\prime} / \mathrm{C}^{\prime}\right), 128.6\left(2 \times \mathrm{ArCH}, \mathrm{C}^{\prime} / \mathrm{C}^{\prime}\right), 56.5\left(\mathrm{CHCH}_{3}, \mathrm{C} 2\right), 40.2$ $\left(\mathrm{NH}_{2}{ }^{+} \mathrm{CH}_{2} \mathrm{CH}_{3}, \mathrm{C} 4\right) ; 20.9\left(\mathrm{ArCH}_{3}, \mathrm{C7}^{\prime}\right), 15.7\left(\mathrm{CHCH}_{3}, \mathrm{C} 3\right)$ and $10.8 \mathrm{ppm}\left(\mathrm{NH}_{2}{ }^{+} \mathrm{CH}_{2} \mathrm{CH}_{3}, \mathrm{C} 5\right)$; LRMS $\left(\mathrm{ESI}^{+}, 70 \mathrm{eV}\right): \mathrm{m} / z=192$ $\left(34,[\mathrm{M}+\mathrm{H}]^{+}\right), 174$ (100), 159 (30), 145 (57), 131 (16), 119 (25) and 91 (6\%); HRMS (ESI ${ }^{+}, 70 \mathrm{eV}$ ) calculated for $[\mathrm{M}+\mathrm{H}]$ $\mathrm{C}_{12} \mathrm{H}_{18} \mathrm{NO}: 192.1383$, found: 192.1381 .

\section{High performance liquid chromatography-amperometric detection (HPLC-AD)}

Reverse phase high-performance liquid chromatography was performed with an integrated Agilent HP Series 1100 Liquid Chromatography Instrument (Agilent Technologies, Wokingham, UK) fitted with an in-line degasser, 100-place autoinjector and single channel, tunable UV absorbance detector (264 nm). The HPLC was coupled, in sequence, to the flow-cell (FC-A or FC-B) housing the GSPE (Fig. 1e) to give the HPLC-AD system. To distinguish the HPLC-AD system employing the impinging jet (FC-A) from the iCell channel (FC-B) flow-cells the two systems were denoted LC-FC-A and LC-FC-B respectively. Data analysis (HPLC-UV) was carried out using ChemStation for LC (Ver. 10.02) software (Agilent Technologies, Wokingham, UK) and amperometric measurements were carried out using a Palmsens (Palm Instruments BV, The Netherlands) potentiostat/galvanostat and controlled by PSTrace version 4.4. All the amperometric measurements were carried out at $22{ }^{\circ} \mathrm{C}$ using the following parameters: (i) potential $(E,+1.4 \mathrm{~V})$; (ii) equilibriation time $\left(t_{\text {equibriation, }} 30 \mathrm{~s}\right)$; (iii) data interval $\left(t_{\text {interval }}, 0.05 \mathrm{~s}\right)$; (iv) current range $(100 \mathrm{nA}-1 \mathrm{~mA})$ and (iv) total run time $\left(t_{\text {run }}, 3000 \mathrm{~s}\right)$. The flow rate was either $0.8 \mathrm{~mL} \min ^{-1}$ (using LC-FC-A) or $1.0 \mathrm{~mL} \mathrm{~min}^{-1}$ (using LC-FC-B) with an injection volume of $10 \mu \mathrm{L}$. The stationary phase (ACE $3 \mathrm{C}_{18}, 150 \mathrm{~mm} \times 4.6 \mathrm{~mm}$ i.d., particle size: $3 \mu \mathrm{m}$ ) used in the study was obtained from HiChrom Limited (Reading, UK). The column was fitted with a guard cartridge (ACE $3 \quad \mathrm{C}_{18}$ ) and maintained at an isothermal temperature of $22{ }^{\circ} \mathrm{C}$ with an Agilent HP Series 1100 column oven with a programmable controller (Agilent Technologies, Wokingham, UK).

\section{Preparation of aqueous $10 \mathrm{mM}$ ammonium acetate-100 $\mathrm{mM}$ potassium chloride buffer ( $\mathrm{pH} 4.3 \pm \mathbf{0 . 0 2}$ )}

$0.77 \mathrm{~g}$ ammonium acetate and $7.46 \mathrm{~g}$ potassium chloride was dissolved in $800 \mathrm{~mL}$ ultrapure deionised water and the $\mathrm{pH}$ of the solution adjusted by dropwise addition of glacial acetic acid to $\mathrm{pH} 4.3( \pm 0.02)$. The mixture was transferred to a $1 \mathrm{~L}$ clear glass volumetric flask and diluted to volume with ultrapure deionised water. The mobile phase [methanol:10 mM ammonium acetate-100 $\mathrm{mM}$ potassium chloride buffer, $30: 70 \% \mathrm{v} / \mathrm{v}$ ] was prepared by separately mixing volumes of the buffer and organic modifier in the appropriate proportions. Prior to use, the mobile phase was vacuum filtered through a $0.45 \mathrm{~mm}$ pore filter paper and degassed for $10 \mathrm{~min}$ at $25{ }^{\circ} \mathrm{C}$ using an ultrasonic bath.

\section{Optimisation of potential for amperometric detection (AD)}

$10.0 \mathrm{mg}$ 4-MMC (2a), 4-MEC (2b) and caffeine were weighed accurately into a $10.0 \mathrm{~mL}$ clear glass volumetric flask and diluted to volume with mobile phase to give a solution containing the three components at $1 \mathrm{mg} \mathrm{mL}^{-1}$. This solution was then further diluted with mobile phase to a standard solution 
containing $100 \mu \mathrm{g} \mathrm{mL} \mathrm{m}^{-1}$ of each analyte. Three replicate injections were performed (using LC-FC-A) and the amperometric response (peak current, $\mu \mathrm{A}$ ), for each analyte, measured as a function of anodic potential $\left(\mathrm{E} \mathrm{V}^{-1}\right)$ over the range +1.1 to +1.4 $\mathrm{E} \mathrm{V}^{-1}$. The data was analysed under the same conditions using PSTrace version 4.4. The optimisation of potential for amperometric detection, for LC-FC-B, was carried out in an analogous manner.

\section{Optimisation of linear velocity for amperometric detection} (AD)

$15.0 \mathrm{mg}$ 4-MMC (2a) was weighed accurately into a $10.0 \mathrm{~mL}$ clear glass volumetric flask and diluted to volume with mobile phase to give a solution containing $4-\mathrm{MMC}$ at $1.5 \mathrm{mg} \mathrm{mL} \mathrm{m}^{-1}$. This solution was then further diluted with mobile phase to a standard solution containing $150 \mu \mathrm{g} \mathrm{mL}^{-1}$ of 4 -MMC. Ten replicate injections were performed (using LC-FC-A) and the amperometric response (peak current, $\mu \mathrm{A}$ ), for $(\mathbf{2 a})$, measured as a function of flow rate over the range 0.8 to $1.0 \mathrm{~mL} \mathrm{~min}^{-1}$. The data was analysed under the same conditions using PSTrace version 4.4. The optimisation of linear velocity for amperometric detection, for LC-FC-B, was carried out in an analogous manner.

\section{Calibration standards}

$10.0 \mathrm{mg}$ 4-MMC (2a), 4-MEC (2b) and caffeine were weighed accurately into a $10.0 \mathrm{~mL}$ clear glass volumetric flask and diluted to volume with mobile phase to give a solution containing the components at $1 \mathrm{mg} \mathrm{mL}{ }^{-1}$. This solution was then further diluted with mobile phase to give calibration standards containing $500 \mu \mathrm{g} \mathrm{mL} \mathrm{m}^{-1}, 400 \mu \mathrm{g} \mathrm{mL}^{-1}, 300 \mu \mathrm{g} \mathrm{mL} \mathrm{L}^{-1}, 200 \mu \mathrm{g}$ $\mathrm{mL}^{-1}, 100 \mu \mathrm{g} \mathrm{mL} \mathrm{m}^{-1}$ and $50 \mu \mathrm{g} \mathrm{mL}^{-1}$ of each analyte.

\section{Specificity standards}

$5.0 \mathrm{mg}$ sucrose, mannitol and lactose were weighed accurately into separate $10.0 \mathrm{~mL}$ clear glass volumetric flask and diluted to volume with mobile phase to give solutions containing the components at $500 \mu \mathrm{g} \mathrm{mL} \mathrm{L}^{-1}$ of each analyte.

\section{Test solutions}

Five samples of NRG-2 were obtained from independent Internet vendors (January 2013) as off-white crystalline powders in clear zip-lock bags. The homogenised samples were arbitrarily labelled NRG-2-A, NRG-2-B, NRG-2-C, NRG-2-D and NRG-2-E. $5.0 \mathrm{mg}$ of each substance was weighed (in triplicate) accurately into a $100.0 \mathrm{~mL}$ clear glass volumetric flask and diluted to volume with mobile phase.

\section{HPLC-UV validation}

The HPLC-UV method, for both systems (LC-FC-A and LC-FC-B), was validated in accordance with the ICH guidelines using the following parameters: linearity, precision, specificity, limit of detection (LOD), limit of quantification (LOQ) and system suitability [resolution $\left(R_{\mathrm{S}}\right)$, column efficiency $(N)$, peak asymmetry $\left.\left(A_{\mathrm{s}}\right)\right]$. Linearity, precision and system suitability tests: six replicate injections of the calibration standards (vide supra) were performed and the data analysed under the same conditions. The \%RSD was calculated for each replicate sample. Specificity: six replicate injections of the specificity standards (vide supra) were performed and the data analysed under the same conditions. Limits of detection and quantification: six replicate injections of the calibration standards (vide supra) were performed and the data analysed under the same conditions. The limits of detection and quantification were calculated based on the standard deviation of the response and the slope.

\section{Amperometric detection (AD) validation}

The amperometric detection (AD) method, for both systems (LC-FC-A and LC-FC-B), was validated using the following parameters: linearity, precision, limit of detection (LOD) and limit of quantification (LOQ). Linearity and precision: six replicate injections of the calibration standards (vide supra) were performed and the data analysed under the same conditions. The $\%$ RSD was calculated for each replicate sample. Limits of detection and quantification: six replicate injections of the calibration standards (vide supra) were performed and the data analysed under the same conditions. The limits of detection and quantification were calculated based on the standard deviation of the response and the slope.

\section{Results and discussion}

Samples of the cathinone standards (2a/2b, Scheme 1) were prepared as their corresponding hydrochloride (or hydrobromide) salts. The synthesis of the racemic compounds was achieved using a modification of the previously reported methods by Santali et al. ${ }^{2}$ and Khreit et al. ${ }^{3}$ from the prerequisite ( \pm )-4'-methyl-2-bromopropiophenone (1) in $51.2 \%$ (2a) and $41.5 \%$ (2b) overall yield, respectively as stable, off-white powders after recrystallization from acetone. To ensure the authenticity of the materials utilised in this study the synthesised samples were fully characterised by ${ }^{1} \mathrm{H}-\mathrm{NMR}$, ${ }^{13} \mathrm{C}-\mathrm{NMR}$, FT-IR and MS (see Experimental section) and the purity of the two standards confirmed by elemental analysis (>99.5\% in both cases).

Khreit et al. have reported the application of HPLC and LC-MS techniques for the analysis of NRG-2 products using an ACE $3 \mathrm{C}_{18}$ column $(150 \mathrm{~mm} \times 4.6 \mathrm{~mm}$ i.d., particle size: $3 \mu \mathrm{m})$ in combination with a mobile phase consisting of methanol: $10 \mathrm{mM}$ ammonium formate $(46: 54 \% \mathrm{v} / \mathrm{v}) .{ }^{3}$ The validated HPLC method (which can detect 4-MMC (2a), 4-MEC (2b) and caffeine at levels of $0.02 \mu \mathrm{g} \mathrm{mL} \mathrm{m}^{-1}$ ) was further developed by Smith $e t$ al. to screen for these analytes in the presence of other synthetic cathinones and benzocaine based on new intelligence received from law enforcement agencies. ${ }^{15}$ A gradient elution program was employed to ensure both optimal detection of the analytes and a rapid analysis time. As gradient elution can affect the performance of electrochemical detectors,$^{25}$ due to changes in the composition of the electrolyte/ eluent employed, the original isocratic method of Khreit et al. 
was adapted to screen for caffeine, 4-MMC and 4-MEC, simultaneously via UV and amperometric detection by employing an mobile phase with a reduced percentage of organic modifier $(30 \% \mathrm{v} / \mathrm{v}$ methanol) in combination with $10 \mathrm{mM}$ ammonium acetate buffer containing a suitable electrolyte $(100 \mathrm{mM} \mathrm{KCl})$. The $\mathrm{pH}$ of the eluent was adjusted to 4.3 both to ensure the cathinones $\left(2 \mathrm{a}: \mathrm{p} K_{\mathrm{a}}=8.69^{2} ; 2 \mathbf{b}: \mathrm{p} K_{\mathrm{a}}=8.88^{3}\right)$ were fully ionised and, as the electrochemical responses of (2a) and (2b) have been shown to be sensitive to $\mathrm{pH}$, to optimise their detection amperometrically. ${ }^{14,15}$

The two amperometric detectors used in this study were either of impinging jet flow cell (FC-A, Fig. $1 \mathrm{a}$ and $b)^{25,26}$ or iCell channel flow cell (FC-B, Fig. 1c and d) ${ }^{24}$ design. The flow cells accommodated the GSPEs without any need for further modification. The optimum configuration (Fig. 1e) of the HPLC-AD system required the amperometric detector to be connected after the UV detector, via PTFE tubing $(230 \times$ $1.6 \mathrm{~mm}$, i.d. $0.3 \mathrm{~mm}$, internal volume: $16.25 \mu \mathrm{L}$ ). This configuration minimised system back-pressure and thereby reduced the leakages (from the flow-cells) observed when the amperometric detector precedes the UV detector. To distinguish the HPLC-AD system employing the impinging jet (FC-A) from the iCell channel (FC-B) flow-cells the two systems were denoted LC-FC-A and LC-FC-B respectively. Based on the previous reported validated HPLC-UV methods, ${ }^{2,3,5,15}$ employed in the separation of caffeine, (2a) and (2b) an ACE $3 \mathrm{C}_{18}$ column was selected and the extra-column volumes associated with the system (e.g. connective tubing and/or flow cell internal volumes) reduced to minimise both eddy- and longitudinaldiffusional processes respectively - thereby optimising the efficiency of a chromatographic resolution between components within a mixture and ensuring the accuracy in their quantification. The anodic over-potential for 4-MMC $(100 \mu \mathrm{g}$ $\mathrm{mL}^{-1}$ ) in the mobile phase was determined using cyclic voltammetry (data not shown) with the peak maxima found to occur at $+1.1 \mathrm{E} \mathrm{V}^{-1}$. Using the peak maxima, in conjunction with the optimised instrumental configuration, the potential required to achieve the optimal detector response (for 2a) was determined, for both LC-FC-A and LC-FC-B, by measuring the amperometric response (peak current, $\mu \mathrm{A}$ ) as a function of anodic potential $\left(\mathrm{E} \mathrm{V}^{-1}\right)$, over the range +1.1 to $+1.4 \mathrm{E} \mathrm{V}^{-1}$. The maximum response $(0.25 \mu \mathrm{A} \pm 2.09 \%, n=3)$ was observed, for (2a), at $+1.4 \mathrm{E} \mathrm{V}^{-1}$ and this potential, which was also shown to be optimal for caffeine $(1.36 \mu \mathrm{A} \pm 1.77 \%, n=3)$ and $(2 \mathbf{b})$ $(0.17 \mu \mathrm{A} \pm 3.15 \%, n=3)$ was used herein for the detection of the target analytes. Due to the variation in internal chamber volumes of the two flow cells (FC-A $=8 \mu \mathrm{L} v s$. FC-B $=120 \mu \mathrm{L}) \mathrm{a}$ solution of $(2 \mathbf{a})\left(150 \mu \mathrm{g} \mathrm{mL}{ }^{-1}\right)$ was injected $(n=10)$ at different flow rates $\left(0.8-1 \mathrm{~mL} \mathrm{~min}^{-1}\right)$ and the amperometric response measured to determine the optimal linear velocity required for maximum amperometric response for each system. The system employing the impinging jet flow cell (LC-FC-A) gave the best response $(+0.47 \mu \mathrm{A} \pm 6.58 \%, n=10)$ at $0.8 \mathrm{~mL} \min ^{-1}$ with higher linear velocities giving a decreased response (circa 19\%) with concomitant increase in back-pressures - due to the nature of the impinging jet design. The corresponding system employing the iCell channel flow cell (LC-FC-B) gave, under similar conditions, the best response $(+0.028 \mu \mathrm{A} \pm 4.94 \%, n=$

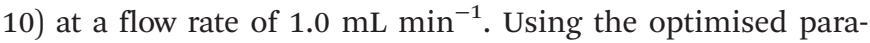
meters (see Experimental section) the standard mixture $\left(500 \mu \mathrm{g} \mathrm{mL}^{-1}\right)$ of caffeine, (2a) and (2b) was rapidly separated on both systems, employing a reverse-phase column (with UV detection), eluting at 5.5 (or 4.3) (caffeine), 9.4 (or 7.5) (4MMC) and 11.7 (or 9.3) minutes (4-MEC) at 0.8 (or 1) $\mathrm{mL}$ $\min ^{-1}$ respectively (see Fig. $2 \mathrm{a}$ and $\mathrm{c}$ ), exhibiting baseline resolution $\left(R_{\mathrm{S}}>2\right)$ with slight peak fronting (asymmetry factor, $A_{\mathrm{s}} \sim$ 0.53-0.64) in each case. The amperometric response (Fig. 2b and d) corresponding to this mixture shows a slight delay of 1.22 (LC-FC-A) and $0.98 \mathrm{~s}$ (LC-FC-B) respectively due to variation in flow rates and the connecting PTFE tubing between the HPLC-UV and AD detectors.

\section{Method validation}

Though it had been demonstrated that a standard mixture $\left(500 \mathrm{mg} \mathrm{mL}^{-1}\right.$ ) of caffeine, 4-MMC (2a) and 4-MEC (2b) could be rapidly separated and detected, using simultaneous UVand amperometric detection, the two LC-AD systems (LC-FC-A and LC-FC-B) required validation prior to deploying them in the analysis of the purchased NRG-2 products. The liquid chromatography-amperometric detection system [LC-FC-A], employing the commercially available, impinging jet, flow cell (FC-A), was validated (in terms of UV-detection) using standard mixtures containing the strongly UV-absorbing components: caffeine, (2a) and (2b) over a 50-500.0 $\mu \mathrm{g} \mathrm{mL} \mathrm{mL}^{-1}$ range. All three analytes demonstrated a linear response $\left(r^{2}=0.999\right)$ with excellent repeatability $(\% \mathrm{RSD}=0.01-0.06 \% ; n=6)$ and the limits of detection for these components were determined (using the standard deviation of the response and the slope of the calibration graph) as being in the range of 2.03-2.99 $\mu \mathrm{g} \mathrm{mL}^{-1}$. Solutions of the UV-inactive analytes sucrose, mannitol, and lactose (which are commonly used as diluents) were shown not to interfere with the three target analytes - thereby confirming the specificity of the proposed method. The limits of quantification were determined (using the standard deviation of the response and the slope) to be 6.14 (caffeine), 7.58 (2a) and $9.05 \mu \mathrm{g} \mathrm{mL}^{-1}(\mathbf{2 b})$ respectively, which is approximately $50 \times$ less sensitive (in terms of limit of quantification) than the previously reported HPLC methods employing UV detection, ${ }^{2,3,5,15}$ however, at concentrations lower than $50 \mu \mathrm{g} \mathrm{mL}{ }^{-1}$, the ability to detect (and accurately quantify) the analytes using amperometry was shown not to be viable.

System suitability tests (resolution, column efficiency $(N)$, height of a theoretical plate $(H)$ and asymmetry factor) were used to verify that the system was performing adequately to ensure confidence in the analytical method and the results obtained. The developed method, for system LC-FC-A, shows that all of the standard system suitability parameters are within acceptable limits. The HPLC-UV validation parameters, for the LC-FC-A system, are summarized in Table 1.

Validation of the LC-FC-A system, in terms of amperometric detection, was carried out using the calibration standards (50-500.0 $\mu \mathrm{g} \mathrm{mL}^{-1}$ ) employed in the UV-detection validation 

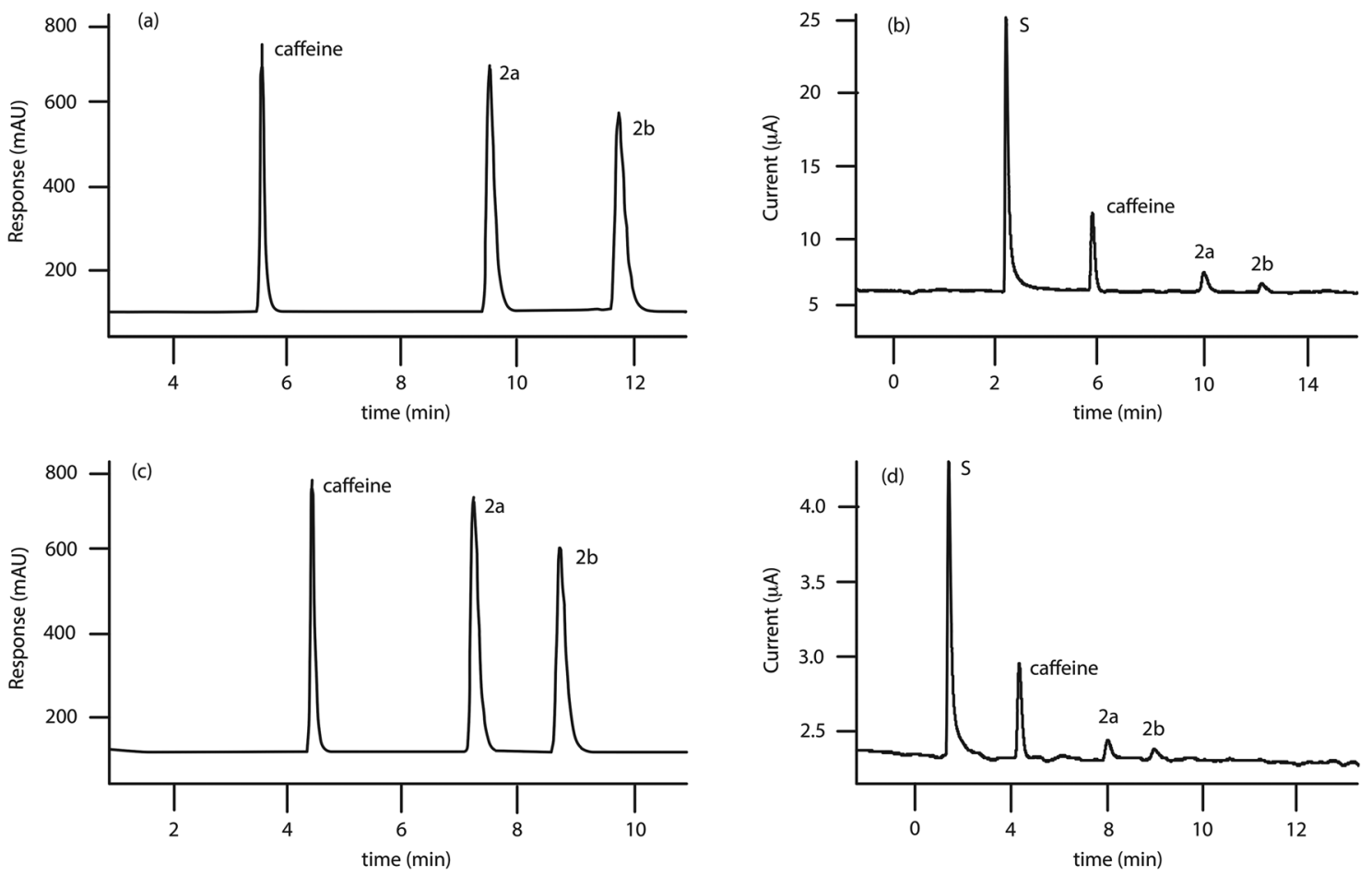

Fig. 2 (a) Representative chromatogram of a solution containing caffeine $\left(500 \mu \mathrm{g} \mathrm{mL}^{-1}\right), 4-\mathrm{MMC}\left(2 \mathrm{a}, 500 \mu \mathrm{g} \mathrm{mL}^{-1}\right)$ and $\left.4-\mathrm{MEC}^{(2 \mathrm{~b}, 500 \mu \mathrm{g} \mathrm{mL}}{ }^{-1}\right)$ obtained on system LC-FC-A using an ACE $3 \mathrm{C}_{18}$ column $(150 \mathrm{~mm} \times 4.6 \mathrm{~mm}$ i.d., particle size: $3 \mu \mathrm{m})$; flow-rate: $0.8 \mathrm{~mL} \mathrm{~min}^{-1}$; mobile phase: methanol: $10 \mathrm{mM}$ ammonium acetate-100 mM potassium chloride ( $\mathrm{pH} 4.3)$ (30:70 v/v); detector wavelength (UV): $264 \mathrm{~nm}$; (b) representative amperogram of a solution containing caffeine $\left(500 \mu \mathrm{g} \mathrm{mL}^{-1}\right), 4-\mathrm{MMC}\left(2 \mathrm{a}, 500 \mu \mathrm{g} \mathrm{mL}^{-1}\right)$ and 4-MEC $\left(2 \mathrm{~b}, 500 \mu \mathrm{gL}^{-1}\right)$ obtained on system LC-FC-A; (c) representative chromatogram of a solution containing caffeine $\left(500 \mu \mathrm{g} \mathrm{mL}^{-1}\right), 4-\mathrm{MMC}\left(2 \mathrm{a}, 500 \mu \mathrm{g} \mathrm{mL}^{-1}\right)$ and 4-MEC (2b, $\left.500 \mu \mathrm{g} \mathrm{mL}{ }^{-1}\right)$ obtained

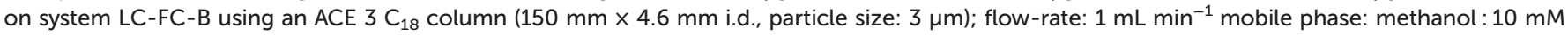
ammonium acetate-100 mM potassium chloride ( $\mathrm{pH} 4.3)(30: 70 \mathrm{v} / \mathrm{v})$; detector wavelength (UV): $264 \mathrm{~nm}$; (d) representative amperogram of a solution containing caffeine $\left(500 \mu \mathrm{g} \mathrm{mL}^{-1}\right), 4-\operatorname{MMC}\left(2 \mathrm{a}, 500 \mu \mathrm{g} \mathrm{mL} \mathrm{L}^{-1}\right)$ and 4-MEC $\left(2 \mathrm{~b}, 500 \mu \mathrm{g} \mathrm{mL}^{-1}\right.$ ) obtained on system LC-FC-B. The $t_{0}$ (for both systems) was determined from the $t_{\mathrm{R}}$ of a solution of uracil $\left(10 \mu \mathrm{g} \mathrm{mL}^{-1}\right)$. The peak $(\mathrm{S})$ is a system peak associated with the sample injection.

study (vide supra) and indicated that (2a), (2b) and caffeine again demonstrated a linear response $\left(r^{2}=0.99\right)$ with good repeatability (\%RSD $=0.32-1.00 \% ; n=6)$. The limits of detection for the analytes were determined to be within the range of 9.35-14.66 $\mu \mathrm{g} \mathrm{mL}^{-1}$ and, though these are approximately $5 \times$ higher than UV-detection, agree with the previously reported levels (11.6-11.8 $\mu \mathrm{g} \mathrm{mL}^{-1}$ ) reported by Smith et al. ${ }^{15}$ The limits of quantification were determined, from the standard deviation of the response and the slope, to be 37.06 (caffeine), 44.42 (4-MMC) and $28.33 \mu \mathrm{g} \mathrm{mL} \mathrm{m}^{-1}$ (4-MEC) respectively. The $\mathrm{AD}$ validation parameters, for the LC-FC-A system, are summarized in Table 2.

The corresponding liquid chromatography-amperometric detection system, [LC-FC-B], employing the iCell channel flow cell (FC-B) was also validated in terms of UV-detection (Table 1) after increasing the flow rate to $1 \mathrm{~mL} \mathrm{~min}^{-1}$ to ensure a satisfactory elution time of the three target analytes (Fig. 2c). As the HPLC-UV detection system was identical to that employed with the impinging jet flow cell, the repeatability, specificity, linear response, limits of detection, limits of quantification and the system suitability tests for the three analytes, showed no significant differences over the $50-500.0 \mu \mathrm{g} \mathrm{mL}^{-1}$ range to the system employing the impinging jet flow cell (LC-FC-A).
Interestingly, in terms of the amperometric detection, the modified system incorporating the iCell channel flow cell (LC-FC-B) demonstrated better repeatability (RSD = $0.07-0.87 \% ; n=6$ ), than LC-FC-A, for the three analytes, however, the linear response was significantly reduced $\left(r^{2}=\right.$ $0.95-0.99)$ over the $200.0-500.0 \mu \mathrm{g} \mathrm{mL} \mathrm{L}^{-1}$ range. The limits of detection for these components were confirmed as being in the range of $23.38-57.92 \mu \mathrm{g} \mathrm{mL} \mathrm{m}^{-1}$ and the limits of quantification were established to be 70.86 (caffeine), 175.51 (2a) and $81.54 \mu \mathrm{g} \mathrm{mL} \mathrm{mL}^{-1}(\mathbf{2 b})$ respectively, which less sensitive than those obtained for impinging jet flow-cell. It is rationalised that in the case of the iCell channel flow cell, the larger chamber volume $(120 \mu \mathrm{L})$, is increasing sample dispersion, diluting the analytes, and thereby reducing the sensitivity of the GSPE sensor platform via mass transfer/diffusion to the electrode surface. ${ }^{27-29}$ The amperometric validation parameters, for the modified system (LC-FC-B), are summarized in Table 2.

\section{Forensic application}

The five NRG-2 samples obtained from Internet vendors (January 2013) were all purported to be $>99 \%$ pure and to contain $1 \mathrm{~g}$ of NRG-2. The samples were homogenised and 
Table 1 Summary of HPLC-UV validation data for the quantification of caffeine, 4-MMC (2a) and 4-MEC (2b) obtained on either the LC-FC-A (impinging jet flow cell) or LC-FC-B (iCell channel flow cell) systems using an ACE $3 \mathrm{C}_{18}$ column (150 mm $\times 4.6 \mathrm{~mm}$ i.d., particle size: $\left.3 \mu \mathrm{m}\right)$; mobile phase: methanol : $10 \mathrm{mM}$ ammonium acetate-100 mM potassium chloride (pH 4.3) $(30: 70 \mathrm{v} / \mathrm{v})$; detector wavelengths (UV): $264 \mathrm{~nm}$. See Fig. $2 \mathrm{a}$ and 2c for representative chromatograms

\begin{tabular}{|c|c|c|c|c|c|c|}
\hline $\begin{array}{l}\text { System (detection) } \\
\text { Flow rate } \\
\text { Analyte }\end{array}$ & \multicolumn{3}{|c|}{$\frac{\text { LC-FC-A (HPLC-UV) }}{0.8 \mathrm{~mL} \mathrm{~min}^{-1}\left(t_{0}=2.01 \mathrm{~min}\right)^{a}}$} & \multicolumn{3}{|c|}{$\frac{\text { LC-FC-B (HPLC-UV })}{1 \mathrm{~mL} \mathrm{~min}^{-1}\left(t_{0}=1.57 \mathrm{~min}\right)^{a}}$} \\
\hline$t_{\mathrm{R}}(\min )$ & 5.5 & 9.4 & 11.7 & 4.3 & 7.5 & 9.3 \\
\hline $\mathrm{RRT}^{b}$ & 0.56 & 1 & 1.24 & 0.57 & 1 & 1.24 \\
\hline $\mathrm{RRF}^{c}$ & 0.8 & 1 & 1.1 & 0.8 & 1 & 1.1 \\
\hline$H(\mathrm{~m})$ & $1.40 \times 10^{-5}$ & $1.15 \times 10^{-5}$ & $1.11 \times 10^{-5}$ & $1.47 \times 10^{-5}$ & $1.17 \times 10^{-5}$ & $1.15 \times 10^{-5}$ \\
\hline Resolution $\left(R_{\mathrm{s}}\right)$ & - & 14.3 & 5.9 & - & 14.2 & 5.98 \\
\hline Asymmetry factor $\left(A_{\mathrm{s}}\right)$ & 0.59 & 0.54 & 0.53 & 0.64 & 0.58 & 0.56 \\
\hline $\operatorname{LOD}^{e}\left(\mu \mathrm{g} \mathrm{mL}^{-1}\right)$ & 2.03 & 2.50 & 2.99 & 1.79 & 1.95 & 2.41 \\
\hline $\mathrm{LOQ}^{f}\left(\mu \mathrm{g} \mathrm{mL}^{-1}\right)$ & 6.14 & 7.58 & 9.05 & 5.43 & 5.90 & 7.29 \\
\hline $\begin{array}{l}\text { Co-efficient of regression } \\
\text { Precision (\%RSD, } n=6)\end{array}$ & $0.999^{g}$ & $0.999^{h}$ & $0.999^{i}$ & $0.999^{j}$ & $0.999^{k}$ & $0.999^{l}$ \\
\hline $400 \mu \mathrm{g} \mathrm{mL}-1$ & 0.06 & 0.05 & 0.05 & 0.01 & 0.02 & 0.06 \\
\hline $500 \mu \mathrm{g} \mathrm{mL}{ }^{-1}$ & 0.02 & 0.04 & 0.04 & 0.02 & 0.16 & 0.16 \\
\hline
\end{tabular}

${ }^{a}$ Determined from the retention time of a solution of uracil $\left(10 \mu \mathrm{g} \mathrm{mL} \mathrm{L}^{-1}\right)$ eluting from the column. ${ }^{b}$ Relative retention time (with respect to 4 MMC, 2a). ${ }^{c}$ Relative response factor (with respect to 4 -MMC, 2a). ${ }^{d} N$ expressed in plates per m. ${ }^{e}$ Limit of detection (based on the standard deviation of the response and the slope). ${ }^{f}$ Limit of quantification (based on the standard deviation of the response and the slope). ${ }^{g} y=28.005 x+$ 17.842. ${ }^{h} y=42.457 x-59.662 .{ }^{i} y=40.176 x-72.103 .{ }^{j} y=22.325 x+31.399 .{ }^{k} y=33.8 x-16.925 .{ }^{l} y=32.083 x-34.811$.

Table 2 Validation of amperometric detection (AD) for the quantification of caffeine, 4-MMC (2a) and 4-MEC (2b) obtained using either the LC-FC-A (impinging jet flow cell) or LC-FC-B (iCell channel flow cell) systems. See Experimental section for parameters used in the amperometric measurements and Fig. $2 \mathrm{~b}$ and $2 \mathrm{~d}$ for representative amperograms

\begin{tabular}{|c|c|c|c|c|c|c|}
\hline $\begin{array}{l}\text { System (detection) } \\
\text { Flow rate }\end{array}$ & \multicolumn{3}{|c|}{ LC-FC-A (AD) } & \multicolumn{3}{|c|}{ LC-FC-B (AD) } \\
\hline$t_{\mathrm{R}}(\min )$ & 5.52 & 9.42 & 11.72 & 4.32 & 7.52 & 9.32 \\
\hline $\operatorname{RRT}^{a}(\min )$ & 0.59 & 1 & 1.24 & 0.57 & 1 & 1.24 \\
\hline $\mathrm{LOD}^{b, e}\left(\mu \mathrm{g} \mathrm{mL}^{-1}\right)$ & 12.23 & 14.66 & 9.35 & 23.38 & 57.92 & 26.91 \\
\hline \multicolumn{7}{|l|}{ Precision (\%RSD, $n=6$ ) } \\
\hline $100 \mu \mathrm{g} \mathrm{mL}-1$ & $\begin{array}{l}0.38 \\
0.32\end{array}$ & $\begin{array}{l}0.55 \\
0.87\end{array}$ & $\begin{array}{l}0.74 \\
0.81\end{array}$ & $\begin{array}{l}\text { n.d. } \\
\text { n.d. }\end{array}$ & $\begin{array}{l}\text { n.d. } \\
\text { n.d. }\end{array}$ & $\begin{array}{l}\text { n.a. } \\
\text { n.d. }\end{array}$ \\
\hline $200 \mu \mathrm{g} \mathrm{mL}^{-1}$ & 0.53 & 0.91 & 1.00 & 0.07 & 0.19 & 0.74 \\
\hline $300 \mu \mathrm{g} \mathrm{mL}{ }^{-1}$ & 0.53 & 0.81 & 0.80 & 0.32 & 0.45 & 0.68 \\
\hline $400 \mu \mathrm{g} \mathrm{mL}{ }^{-1}$ & 0.71 & 0.91 & 1.00 & 0.15 & 0.55 & 0.45 \\
\hline $500 \mu \mathrm{g} \mathrm{mL}{ }^{-1}$ & 0.57 & 0.87 & 0.48 & 0.10 & 0.87 & 0.38 \\
\hline
\end{tabular}

n.d. $=$ not determined. ${ }^{a}$ Relative retention time (with respect to 4-MMC, 2a). ${ }^{b}$ limit of detection (based on the standard deviation of the response and the slope). ${ }^{c}$ Limit of quantification (based on the standard deviation of the response and the slope). ${ }^{d} y=0.0105 x+0.2039 .{ }^{e} y=0.0025 x-$ $0.0211 .{ }^{f} y=0.0011 x+0.0082 .{ }^{g} y=0.0013 x+0.0563 .{ }^{h} y=0.0003 x+0.0053 .{ }^{i} y=0.00009 x+0.026$.

arbitrarily labelled NRG-2-A, NRG-2-B, NRG-2-C, NRG-2-D and NRG-2-E. Preliminary LC-MS analysis indicated that all five samples contained synthetic cathinones. The synthetic cathi- nones 4-MMC (2a) or 4-MEC (2b) were either pure ${ }^{3}$ (NRG-2-A: $t_{\mathrm{R}}=5.34 \min \left[m / z=192.2[\mathrm{M}+\mathrm{H}]^{+}, 4-\mathrm{MEC}\right]$; NRG-2-B: $t_{\mathrm{R}}=$ $\left.4.48 \min \left[m / z=178.1[\mathrm{M}+\mathrm{H}]^{+}, 4-\mathrm{MMC}\right]\right)$; adulterated with 
significant quantities of caffeine ${ }^{15}$ (NRG-2-C: $t_{\mathrm{R}}=2.57 \mathrm{~min}$ [major, $\mathrm{m} / z=195.1[\mathrm{M}+\mathrm{H}]^{+}$, caffeine]; 5.34 min [minor, $\left.m / z=192.2[\mathrm{M}+\mathrm{H}]^{+}, 4-\mathrm{MEC}\right]$; NRG-2-D: $t_{\mathrm{R}}=2.57$ min [major, $\mathrm{m} / \mathrm{z}=195.1[\mathrm{M}+\mathrm{H}]^{+}$, caffeine]; $4.48 \mathrm{~min}$ [minor, $\mathrm{m} / \mathrm{z}=178.1$ $\left.\left.[\mathrm{M}+\mathrm{H}]^{+}, 4-\mathrm{MMC}\right]\right)$ or combined together with caffeine (NRG-2$\mathrm{E}: t_{\mathrm{R}}=2.57 \mathrm{~min}\left[\mathrm{~m} / \mathrm{z}=195.1[\mathrm{M}+\mathrm{H}]^{+}\right.$, caffeine $]$; $4.48 \mathrm{~min}$ $\left[\mathrm{m} / \mathrm{z}=178.1[\mathrm{M}+\mathrm{H}]^{+}, 4-\mathrm{MMC}\right] ; 5.34 \mathrm{~min}\left[\mathrm{~m} / \mathrm{z}=192.2[\mathrm{M}+\mathrm{H}]^{+}\right.$, 4-MEC]) (Table 3).

With substantial evidence supporting an electroanalytical oxidation approach for detecting various substituted cathinones in street samples the viability of the proposed protocol was tested. The NRG-2 samples were reanalysed (in triplicate) using the validated LC-AD method, using both flow cells, at a concentration of $500 \mu \mathrm{g} \mathrm{mL}{ }^{-1}$. The HPLC-UV results (Table 3), obtained using the system employing the impinging jet flow cell (LC-FC-A), confirmed that two of the samples contained only synthetic cathinones (NRG-2-A: $24.03 \pm 0.03 \%$ w/w 4-MEC and NRG-2-B: $49.24 \pm 0.03 \% \mathrm{w} / \mathrm{w}$ 4-MMC); two of the samples contained predominantly caffeine (circa $80 \% \mathrm{w} / \mathrm{w}$ ) in combination with 4-MMC or 4-MEC (NRG-2-C: $76.19 \pm 0.22 \% \mathrm{w} / \mathrm{w}$ caffeine, $23.58 \pm 0.49 \% \mathrm{w} / \mathrm{w}$ 4-MEC and NRG-2-D: $83.04 \pm$ $0.03 \% \mathrm{w} / \mathrm{w}$ caffeine, $15.64 \pm 0.45 \% \mathrm{w} / \mathrm{w} 4-\mathrm{MMC}$ ) and one sample contained a complex mixture of the three analytes (NRG-2-E: $36.55 \pm 0.08 \% \mathrm{w} / \mathrm{w}$ caffeine, $15.64 \pm 0.46 \% \mathrm{w} / \mathrm{w} 4-$ MMC, $24.03 \pm 0.03 \% \mathrm{w} / \mathrm{w}$ 4-MEC). These observations are in agreement with the information reported by Khreit et al., Brandt et al. and Smith et al. who noted that many secondgeneration "legal high" products contained increased levels of commonly used diluents and adulterants. ${ }^{3,4,15}$

The qualitative results, obtained from the amperometric detector (LC-FC-A), also confirmed the constitution of the five NRG-2 samples and comparison of two methods (HPLC-UV vs. $\mathrm{AD}$, Table 4) indicated that in samples containing caffeine (NRG-2-C, NRG-2-D and NRG-2-E) the two methods were comparable in terms of their ability to quantify the levels of caffeine present (NRG-2-C, HPLC-UV: $76.19 \pm 0.22 \% \mathrm{w} / \mathrm{w}$ vs. AD: $78.26 \pm 0.68 \% \mathrm{w} / \mathrm{w}$; NRG-2-D, HPLC-UV: $83.04 \pm 0.03 \% \mathrm{w} /$ w vs. AD: $80.54 \pm 2.06 \% \mathrm{w} / \mathrm{w}$; NRG-2-E, HPLC-UV: $36.55 \pm$ $0.08 \% \mathrm{w} / \mathrm{w} v s$. AD: $42.22 \pm 1.43 \% \mathrm{w} / \mathrm{w})$.

Samples containing only 4-MMC and 4-MEC (NRG-2-A and NRG-2-B) showed a significant over estimation of the quantities of the synthetic cathinones present in comparison to the HPLC-UV detection (NRG-2-A, HPLC-UV: $24.03 \pm 0.03 \% \mathrm{w} / \mathrm{w}$ 4MEC vs. AD: $54.39 \pm 1.24 \%$ w/w 4-MEC; NRG-2-B, HPLC-UV: $49.24 \pm 0.03 \% \mathrm{w} / \mathrm{w} 4-\mathrm{MMC} v s . \mathrm{AD}: 60.80 \pm 0.57 \% \mathrm{w} / \mathrm{w} 4-\mathrm{MMC})$ and though a new GSPE was utilised during each sample analysis, the loss in analytical performance, in terms of the inconsistency, maybe due to adsorption of the synthetic cathinones onto the surface of the GSPE during the timescale of the analysis.

Yao et al. has recently reported that purine bases have the ability to adsorb competitively onto the surface of carbon electrodes. ${ }^{30}$ As caffeine, which is structurally similar to purine, is present in the NRG-2-C and NRG-2-D samples, it is feasible that it may compete, with the synthetic cathinones, for sites on the surface of the GSPE. This may explain the increase

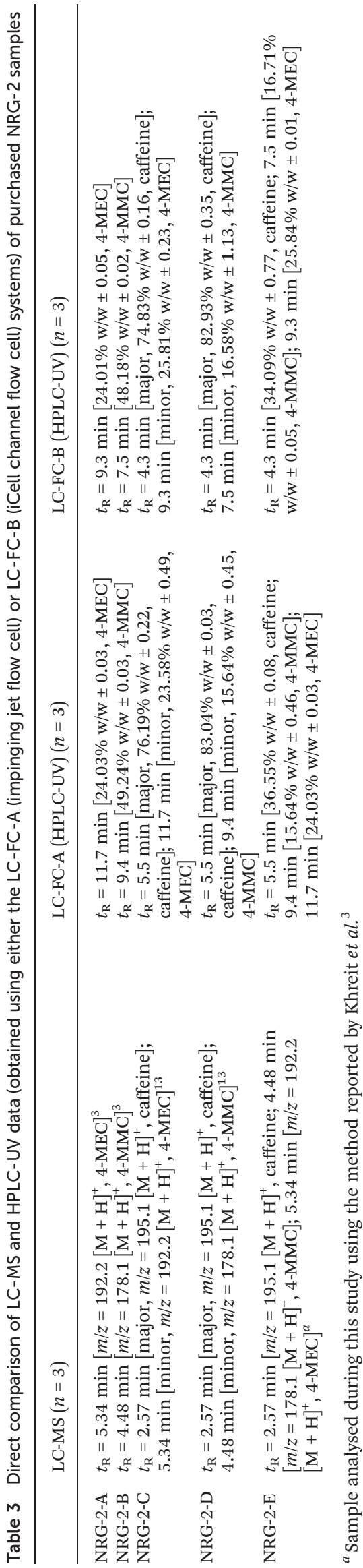


Table 4 Direct comparison between quantitative data obtained by HPLC-UV and amperometric detection (AD), using either the LC-FC-A (impinging jet flow cell) or LC-FC-B (iCell channel flow cell) systems, for the analysis of the synthetic cathinones in a selection of purchased NRG-2 samples

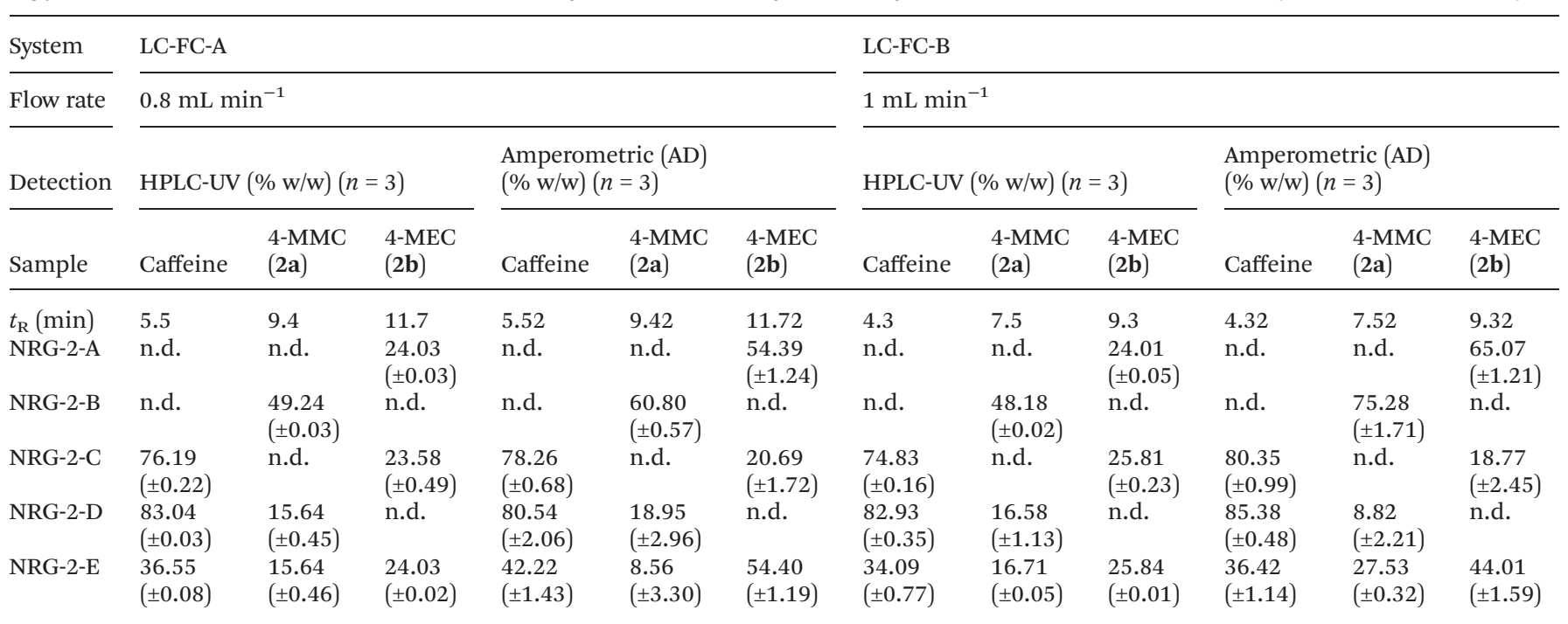

n.d. $=$ not detected.

observed in the levels of caffeine, and more consistent quantification of 4-MMC and 4-MEC, present when HPLC-UV and amperometric detection, of these samples, are contrasted (NRG-2-C, HPLC-UV: $76.19 \pm 0.22 \% \mathrm{w} / \mathrm{w}$ caffeine, $23.58 \pm$ $0.22 \% \mathrm{w} / \mathrm{w}$ 4-MEC $v s$. AD: $78.26 \pm 0.68 \% \mathrm{w} / \mathrm{w}$ caffeine, $20.69 \pm$ $1.72 \% \mathrm{w} / \mathrm{w}$ 4-MEC; NRG-2-D, HPLC-UV: $83.04 \pm 0.03 \% \mathrm{w} / \mathrm{w}$ caffeine, $15.64 \pm 0.45 \% \mathrm{w} / \mathrm{w} 4-\mathrm{MMC}$ vs. AD: $80.54 \pm 2.06 \% \mathrm{w} / \mathrm{w}$ caffeine $18.95 \pm 2.96 \% \mathrm{w} / \mathrm{w} 4$-MEC). Though a good correlation between the HPLC-UV and amperometric methods was observed for the fifth sample, NRG-2-E, in terms of their ability to quantify the levels of caffeine. Interestingly, by contrasting the two detection methods, the levels of 4-MEC (2b) were overestimated and 4-MMC (2a) was underestimated amperometrically in the case of NRG-2-E (NRG-2-E, HPLC-UV: $36.55 \pm 0.08 \% \mathrm{w} / \mathrm{w}$ caffeine, $15.64 \pm 0.46 \% \mathrm{w} / \mathrm{w}$ 4-MMC, $24.03 \pm$ $0.02 \% \mathrm{w} / \mathrm{w} 4$-MEC $v s$. AD: $42.22 \pm 1.43 \% \mathrm{w} / \mathrm{w}$ caffeine, $8.56 \pm$ $3.30 \% \mathrm{w} / \mathrm{w}$ 4-MMC, $54.40 \pm 1.19 \% \mathrm{w} / \mathrm{w}$ 4-MEC). These observations are difficult to rationalise as simple analyte adsorption on to the GSPE surface as the efficient chromatographic separation of the target analytes, before their detection, should intrinsically contribute to avoid competitive adsorption. Additionally within the system, there may not be enough time for one analyte (or other adsorbates) to occupy all the adsorption sites on the electrode in a flowing system, and the solution flowing may effectively make the analytes desorbed before detection of other analytes.

The NRG-2 samples were also analysed using the modified liquid chromatography-amperometric detection system, [LC-FC-B] at a concentration of $500 \mu \mathrm{g} \mathrm{mL} \mathrm{m}^{-1}$. The HPLC-UV results, obtained using the system employing the iCell channel flow cell (LC-FC-B), showed no significant differences and were consistent with those observed on the LC-FC-A (Table 3) utilising the impinging jet flow cell. The amperometric detection results follow a similar trend to those observed with LC-FC-A, however, in the case the sample containing caffeine, (2a) and (2b) (NRG-2-E), the results show an over estimation of the synthetic cathinones. This variation in the results may again be due to the adsorption of the analytes onto the surface of the GSPE. However, as the iCell channel flow cell (FC-B) has a larger chamber volume, the effect of reduced mass transfer/ diffusion to the electrode surface, due to sample dispersion may also be a factor in reducing the sensitivity of the GSPE sensor platform.

In summary, though our LC-AD system has lower sensitivity than simple HPLC-UV, ${ }^{5}$ this work demonstrates an improvement over our previous work, which indicated that there was no electrochemical selectivity of the electrochemical detection of 4-MMC and 4-MEC. Efficient chromatographic separation of these analytes, before their detection, allows us to now rapidly separate, discriminate between and quantify, two structurally related cathinones within a complex street sample mixtures (Table 4) indicating that the proposed HPLC-AD protocol can be considered suitable for the detection and quantification of the two synthetic cathinones either in their pure form, in the presence of common adulterants (e.g. caffeine) or simultaneously within blended street samples of the evolved "legal high" product, NRG-2. We concede that the observed amperometric limits of detection (for the electrochemical oxidation of 4-MMC and 4-MEC) reported herein are lower to the values reported in our previous work ${ }^{5}$ (2a: $39.8 \mu \mathrm{g} \mathrm{mL} \mathrm{mL}^{-1}$ and $2 \mathbf{b}$ : $84.2 \mu \mathrm{g} \mathrm{mL}{ }^{-1}$ ), however, this is sufficient for use in the field opposed to the values reported by Krishnaiah et al. ${ }^{16}$ who utilised a dropping mercury electrode (DME) which is not suitable for use in the field and banned in many countries. Notwithstanding the loss in analytical performance, when compared to HPLC-UV detection, this proof-of-concept study is 
still adequate for quantifying the synthetic cathinones present within seized samples and work to (i) ascertain the physical processes at the electrode surface; (ii) optimise of the shape of the flow cell to yield greater sensitivity and (iii) employ microfluidics to develop a miniaturised detection system which can be employed in the field testing of new psychoactive substances is currently underway.

\section{Conclusions}

For the first time, the combination of HPLC with amperometric detection for the qualitative and quantitative analysis of synthetic cathinones (4-MMC and 4-MEC) has been reported using either an impinging jet flow (LC-FC-A) or iCell channel flow (LC-FC-B) cell incorporating disposable embedded graphite screen-printed macroelectrodes (GSPE). The two high performance liquid chromatography-amperometric detection (HPLC-AD) systems have similar limits of detection, in terms of amperometric detection [LC-FC-A: $14.66 \mu \mathrm{g} \mathrm{mL}^{-1}$ (2a) and $9.35 \mu \mathrm{g} \mathrm{mL} \mathrm{mL}^{-1}$ (2b); LC-FC-B: $57.92 \mu \mathrm{g}$ $\mathrm{mL}^{-1}(\mathbf{2 a})$ and $\left.26.91 \mu \mathrm{g} \mathrm{mL} \mathrm{mL}^{-1}(\mathbf{2 b})\right]$, to the previously reported oxidative electrochemical protocol, ${ }^{5}$ for two synthetic cathinones, prevalent on the recreational drugs market. [39.8 $\mu \mathrm{g}$ $\mathrm{mL}^{-1}(\mathbf{2 a})$ and $\left.84.2 \mu \mathrm{g} \mathrm{mL} \mathrm{mL}^{-1}(\mathbf{2 b})\right]$. Though not as sensitive as standard HPLC-UV detection, both flow cells show a good agreement, between the quantitative electroanalytical data, thereby making them suitable for the detection and quantification of 4-MMC and 4-MEC, either in their pure form or within complex mixtures. It is noted that the impinging jet flow cell (FC-A) appeared to be slightly more sensitive than the iCell current flow cell (FC-B) and this reduction in sensitivity is believed to be a direct result of the larger internal volume, of the iCell, which increases sample dispersion, thereby reducing the sensitivity of the GSPE sensor platform. This work also demonstrates the design of the flow-cell affects the overall sensitivity of the measurement system, with the flow-cell having the smaller fluid volume giving a greater response. However the two designs are significantly different in terms of the flow delivery to the electrode yet the iCell (having a volume 15 times that of the impinging jet flow cell) gives detection results of a similar order. This suggests further optimisation of the shape may yield greater sensitivity; such work is underway with NPS and the HPLC-AD protocol. The simultaneous HPLC-UV and amperometric detection protocol detailed herein shows a marked improvement and advantage over previously reported electroanalytical methods, which were either unable to selectively discriminate between structurally related synthetic cathinones or utilised harmful and restrictive materials in their design. It is envisaged that the proof-of-concept study will be invaluable, to analytical scientists and law enforcement officials, for the development of miniaturised and robust, electroanalytical detection systems for New Psychoactive Substances and related compounds as they emerge on the recreational drugs market.

\section{Acknowledgements}

We thank the British Council for supporting this research (Institutional Link, grant no. 172726574) and the Libyan Cultural Bureau for the provision of a studentship for KYZ.

\section{References}

1 J. Killebrand, D. Olszewski and R. Sedefov, Substance Use Misuse, 2010, 45, 330-340.

2 E. Y. Santali, A.-K. Cadogan, N. Nic Daeid, K. A. Savage and O. B. Sutcliffe, J. Pharm. Biomed. Anal., 2011, 56, 246-255.

3 O. I. G. Khreit, C. Irving, E. Schmidt, J. A. Parkinson, N. Nic Daeid and O. B. Sutcliffe, J. Pharm. Biomed. Anal., 2012, 61, 122-135.

4 S. D. Brandt, S. Freeman, H. R. Sumnall, F. Measham and J. Cole, Drug Test. Anal., 2010, 2, 377-382.

5 J. P. Smith, J. P. Metters, C. Irving, O. B. Sutcliffe and C. E. Banks, Analyst, 2014, 139, 389-400.

6 K. Y. Rust, M. R. Baumgartner, A. M. Dally and T. Kraemer, Drug Test Anal., 2012, 4(6), 402-408.

7 D. Gil, P. Adamowicz, A. Skulska, B. Tokarczyk and R. Stanaszek, Forensic Sci. Int., 2013, 228, e11-e15.

8 J. P. Smith, O. B. Sutcliffe and C. E. Banks, Analyst, 2015, 140, 4932-4948.

9 J. P. Metters, R. O. Kadara and C. E. Banks, Analyst, 2011, 136, 1067-1076.

10 J. P. Metters, F. Tan and C. E. Banks, J. Solid State Electrochem., 2013, 17, 1553-1562.

11 J. P. Metters, M. Gomez-Mingot, J. Iniesta, R. O. Kadara and C. E. Banks, Sens. Actuators, B, 2013, 177, 1043-1052.

12 A. V. Kolliopoulos, J. P. Metters and C. E. Banks, Anal. Methods, 2013, 5, 851-856.

13 O. Ramdani, J. P. Metters, L. C. S. Figueiredo, O. Fatibello and C. E. Banks, Analyst, 2013, 138, 1053-1059.

14 J. P. Smith, J. P. Metters, D. K. Kampouris, C. Lledo-Fernandez, O. B. Sutcliffe and C. E. Banks, Analyst, 2013, 138, 6185-6191.

15 J. P. Smith, J. P. Metters, O. I. G. Khreit, O. B. Sutcliffe and C. E. Banks, Anal. Chem., 2014, 86, 9985-9992.

16 V. Krishnaiah, Y. V. Rami Reddy, V. Hanuman Reddy, M. Thirupalu Reddy and G. M. Rao, Int. J. Sci. Res., 2012, 1, 14-17.

17 I. Morales Fuentes and R. Reyes Gil, Rev. Saude Publica, 2003, 37, 266-272.

18 O. InSug, S. Datar, C. J. Koch, I. M. Shapiro and B. J. Shenker, Toxicology, 1997, 124, 211-224.

19 J. A. Marcusson, B. Carlmark and C. Jarstrand, Environ. Res., 2000, 83, 123-128.

20 G. Sandborgh-Englund, C. G. Elinder, G. Johanson, B. Lind, I. Skare and J. Ekstrand, Toxicol. Appl. Pharmacol., 1998, 150, 146-153.

21 F. Kusu, Chromatogr. Sci. Ser., 2012, 104, 187-219.

22 F. Kusu, Yakugaku Zasshi, 2015, 135(3), 415-430. 
23 R. J. Flanagan, D. Perrett and R. Whelpton, Electrochemical Detection in HPLC: Analysis of Drugs and Poisons, RSC Chromatography Monographs, 2005, vol. 10, pp. 1-244.

24 D. J. Pike, N. Kapur, P. A. Milner and D. I. Stewart, Sensors, 2013, 13, 58-70.

25 H. Gunasingham, B. Tay and D. C. Chapital, J. Chromatogr., 1984, 285(1), 103-114.

26 H. Gunasingham, Anal. Chim. Acta, 1984, 159, 139-147.
27 R. Guidelli, J. Electroanal. Chem. Interfacial Electrochem., 1971, 33(2), 291-302.

28 R. Guidelli, J. Electroanal. Chem. Interfacial Electrochem., 1971, 33(2), 303-317.

29 K. B. Oldham, J. Electroanal. Chem. Interfacial Electrochem., 1973, 41(3), 351-358.

30 Y. Zhou, H. Yan, Q. Xie and S. Yao, Talanta, 2015, 134, 354-359. 